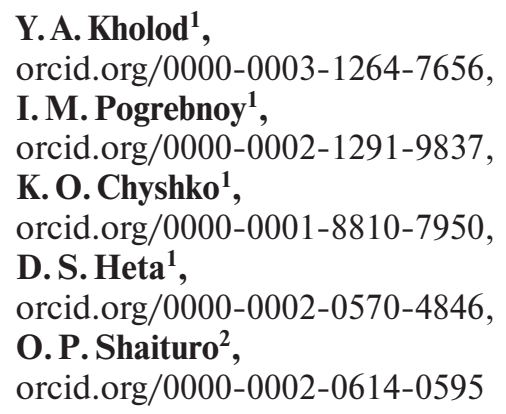

1 - Kharkiv National University of Internal Affairs, Kharkiv, Ukraine

2 - Karazin Kharkiv National University, Kharkiv, Ukraine, e-mail: opshaituro@karazin.ua

\title{
PROTECTION OF PUBLIC RELATIONS IN THE FIELD OF AMBER MINING IN UKRAINE: LEGAL ASPECT
}

Purpose. Defining legal means of protection of public relations in the field of amber mining in Ukraine, providing scientific and practical interpretation of protection legislation in this area and scientifically sound recommendations for its improvement.

Methodology. The methodological basis of the study is a system of general and special methods of cognition: the dialectical method was used to learn the essence of such a phenomenon as the protection of public relations in the field of amber mining in Ukraine; the system-structural method - in the analysis of forms of socially dangerous acts of crimes under Art. Art. 240, 240-1 of the Criminal Code of Ukraine; the logical-dogmatic method - when interpreting certain terms used in the sciences of geology, administrative and criminal law, contained in the provisions of current legislation, as well as in formulating definitions of legal concepts and developing recommendations for improving legal norms; the comparative law method - in the study on the ratio of socially dangerous acts under Art. Art. 201-1, 240, 240-1, 305 of the Criminal Code of Ukraine; general methods (analysis, synthesis, induction, deduction, abstraction, generalization) - in the study on scientific and regulatory sources.

Findings. As a result of the study, the inconsistency of certain norms of criminal, administrative and customs legislation was established, which form the components of offenses in the field of illegal amber mining in Ukraine and establish the types and extent of responsibility for their commission, in particular: competition of certain norms, their inefficiency, disproportionate severity violation of the degree of their social danger. The scientific and practical interpretation is given of the forms of socially dangerous act provided by Art. 240-1 of the Criminal Code of Ukraine, a comparative analysis is conducted of criminal, administrative and customs offenses in this area and proposals are provided to improve criminal, administrative and customs legislation, the rules of which protect public relations in the field of amber mining in Ukraine.

Originality. It is proposed: 1) to supplement the Criminal Code of Ukraine, Art. 240-2, which provides for criminal liability for amber smuggling; 2) to supplement Chapter 68 of the Customs Code of Ukraine with Article 483-1, which provides for administrative liability for smuggling of amber in small amounts; 3) to supplement the Code of Ukraine on Administrative Offenses with Article 58-2, which provides for administrative liability for illegal extraction of amber, its sale, purchase, storage, transfer, shipment, transportation, processing in small amounts.

Practical value. Proposals to improve the current criminal, administrative and customs legislation are aimed at improving the effectiveness of law enforcement agencies against illegal amber mining in Ukraine.

Keywords: protection of subsoil of Ukraine, illegal amber mining, criminal and administrative liability

Introduction. The term "amber" refers to the types of fossil resins used in the jewelry industry: succinite, blush, birmite, simethite, retinite, hedanite, chemoinite, glacier [1]. In essence, amber is a precious stone formed by the crystallization of the resin of ancient conifers for several million years without access to oxygen. The legislation of Ukraine refers amber to the category of jewelry raw materials and gives it national significance [2]. Ukraine has one of the largest reserves of amber in Europe and ranks second in the world in terms of deposits of this mineral, has the world's highest percentage of amber jewelry quality [3]. According to the State Service of Geology and Subsoil of Ukraine, the main reserves of amber are concentrated in the Prypiat amber basin, which includes the northern parts of Kyiv, Zhytomyr, Volyn and Rivne regions. According to experts, the productive area of these deposits is 10 thousand $\mathrm{km}^{2}$ with projected amber resources over 100 thousand tons [4]. However, according to expert studies, despite the voluminous deposits of this mineral, national companies that have special permits for its production annually produce only about 4 tons of amber. Illegal fishing, which is out of state control, accounts for a much larger volume of production - from 120 to 300 tons per year. The annual income from the illegal sale of Ukrainian amber on the black market

(C) Kholod Y.A., Pogrebnoy I. M., Chyshko K. O., Heta D. S., Shaituro O.P., 2021 and its smuggled exports from Ukraine is estimated at 300 to 320 million US dollars [5].

Illegal amber extraction leads to a number of negative environmental, economic and social consequences of this action. In particular, according to the experts, the ecological consequences should include: violation of the unity of geological layers, depletion of amber subsoil, violation of hydrogeological conditions in the surrounding areas, destruction of grass cover and fertile soil, felling of trees and violation of their root system, change in wetland biocenoses. Overcoming these consequences requires the reclamation of disturbed lands, conservation of natural resources and complexes. The economic consequences of uncontrolled amber mining include losses in forestry and water management, soil degradation, loss of significant amounts of raw amber for the state, failure to receive customs, national and local taxes and fees. The social consequences are manifested in the growing level of criminogenic situation in the regions, injuries and deaths among miners due to noncompliance with safety rules, increasing social tensions due to conflicts between miners and ordinary citizens [3].

Literature review. Researchers V. L. Bredikhina, V. I. Tsymbalyuk, Yu. A. Turlova, G. S. Polishchuk studied the problems of legal protection of public relations in the field of amber mining in Ukraine. There are also works on the study of subsoil protection problems in EU countries [6]. The works of these scientists were aimed at solving the problems of public 
administration of amber mining in Ukraine, highlighting the causes and consequences of illegal activities in this area, criminalization of illegal amber mining and do not contain specific proposals to improve existing legislation to combat illegal amber mining. Other scientists, such as O. O. Dudorov, M. V. Komaritsky, D. O. Kalmykov, N.V. Netesa studied the problems of criminal liability for illegal mining in general, which did not allow them to dwell more on the key and aspects and features of legal liability for illegal amber mining. In addition, the Law of Ukraine "On Amendments to Certain Legislative Acts of Ukraine to Improve the Legislation on the Extraction of Amber and Other Minerals" of December 19, 2019 No. 402 [7] amended the Criminal Code of Ukraine Art. 240-1 [8], which provides for liability for illegal amber mining, as well as sale, purchase, storage, transfer, shipment, transportation, processing of amber, the legality of which is not confirmed by relevant documents. These legislative changes have raised a number of questions about the qualification of these new crimes, their relationship.

Purpose. Defining legal means of protection of public relations in the field of amber mining in Ukraine, providing scientific and practical interpretation of protection legislation in this area and scientifically sound recommendations for their improvement. The purpose of the study is achieved through the consistent solving of the following tasks:

- research into literary sources and normative-legal acts, in which the existing criminal and administrative norms are described and fixed, which protect public relations in the field of amber mining;

- analysis of certain norms of criminal, administrative and customs legislation, which form the components of offenses in the field of illegal amber mining in Ukraine and establish the types and extent of responsibility for their commission;

- providing scientific and practical interpretation of forms of socially dangerous acts provided for in Art. 240-1 of the Criminal Code of Ukraine;

- comparative analysis of the composition of criminal and administrative offenses in this area;

- submission of proposals for the improvement of criminal, administrative and customs legislation, the norms of which protect public relations in the field of amber mining in Ukraine.

Methods. The methodological basis of the study is a system of general and special methods of cognition: the dialectical method was used to learn the essence of such a phenomenon as the protection of public relations in the field of amber mining in Ukraine; the system-structural method - in the analysis of forms of socially dangerous acts of crimes under Art. Art. 240, 240-1 of the Criminal Code of Ukraine; the logical-dogmatic method - when interpreting certain terms used in the sciences of geology, administrative and criminal law, contained in the provisions of current legislation, as well as in formulating definitions of legal concepts and developing recommendations for improving legal norms; the comparative law method - in the study on the ratio of socially dangerous acts under Art. Art. 201-1, 240, 240-1, 305 of the Criminal Code of Ukraine; general methods (analysis, synthesis, induction, deduction, abstraction, generalization) - in the study of scientific and regulatory sources.

Results. From the point of view of legal science, all amber management activities form a certain sphere of social relations, which are the object of legal regulation and protection by the state. The Verkhovna Rada of Ukraine has repeatedly tried to settle the issue of amber mining. Thus, the Verkhovna Rada of Ukraine considered several draft laws, including the Draft Law "On Amber" of December 29, 2009 No. 5497; "On the peculiarities of raw amber mining in deposits and manifestations that have no industrial significance" dd. 10.12.2014 No. 1351; "On the extraction and sale of amber" dd. 26.12.2014 No. 1351-1. However, all of them did not find support in parliament. Finally, on December 19, 2019, the Law of Ukraine
No. 402 "On Amendments to Certain Legislative Acts of Ukraine Concerning the Improvement of Legislation on Extraction of Amber and Other Minerals" was adopted. Changes in the legal regulation addressed the following main issues: the Subsoil Code of Ukraine includes a separate concept of a special permit for geological study on amber subsoil, including research and development of deposits with subsequent extraction of amber [9]; the Tax Code of Ukraine provides for a reduction in the rent for the use of subsoil for the purpose of amber mining [10]; the Land Code of Ukraine includes the right to obtain land plots for research and industrial development of amber deposits and defines the rules for their use [11]; the Criminal Code of Ukraine provides for liability for illegal extraction, sale, acquisition, transfer, shipment, transportation, processing of amber, the legality of which is not confirmed by relevant documents, and so on.

Thus, the state reform in the field of legal regulation of amber mining in Ukraine also affected criminal law. But this does not mean that until December 19, 2019, illegal acts of amber mining were not criminalized. Since the adoption of the current Criminal Code of Ukraine in 2001, criminal liability was introduced for illegal mining (Article 240 of the Criminal Code of Ukraine). It is not difficult to note that at that time the criminal law did not provide for a special rule that would provide for criminal liability for illegal amber mining. This subject of a crime was included in the structure of the criminal offense provided by Art. 240 of the Criminal Code of Ukraine, along with other similar items - types of minerals: gas, oil, coal, metals, and others. With the adoption of Art. 240-1 the range of types of illegal amber handling was expanded, along with illegal mining, which are criminally punishable: sale, purchase, transfer, shipment, transportation, processing of amber.

Along with this, the entry into force of Art. 240-1 of the Criminal code of Ukraine does not provide cancellation or change of Art. 240 of the Criminal Code. Therefore, in this connection there is a question of delimitation of the crimes provided by Art. 240 and Art. 240-1 of the Criminal Code of Ukraine.

In general, Art. 240 of the Criminal Code of Ukraine provides for criminal liability for the following main components of crimes: 1) violation of the established rules of subsoil protection, if it has created a danger to life, human health or the environment; 2) violation of the established rules of subsoil use, if it has created a danger to life, human health or the environment, as well as illegal extraction of minerals of national importance.

Article 240-1, in turn, provides for criminal liability for illegal amber mining, as well as sale, purchase, storage, transfer, shipment, transportation, processing of amber, the legality of which is not confirmed by relevant documents.

Under the use of subsoil according to Art. 14 of the Subsoil Code of Ukraine means: their geological study; mining; construction and operation of underground structures not related to the extraction of minerals; creation of geological territories and objects of important scientific, cultural, sanitary and health significance; geological study of amber subsoil, and so on.

Thus, amber mining falls under the statutory concept of "subsoil use" and at first glance illegal actions of amber mining should be qualified under Part 2 of Art. 240 of the Criminal Code of Ukraine. However, Part 1 of Art. 240-1 also stipulates that illegal amber mining is one of the independent forms of socially dangerous act of this crime. Thus, there is a legal conflict or competition of criminal law.

Criminal science is familiar with such concepts as competition of general and special criminal law. Practical recommendations for overcoming them are that priority is given to a special rule, which, accordingly, should be used to qualify a socially dangerous act. In the context of our study, the general rule is Part 2 of Art. 240 of the Criminal Code of Ukraine, and a special part 1 of Art. 240-1 of the Criminal Code of Ukraine. The former establishes criminal liability for illegal extraction of all types of minerals of national importance. The latter con- 
cerns the issue of criminal liability for the extraction of amber only.

Along with this, the novelty of the Special Part of the Criminal Code of Ukraine significantly expands the range of socially dangerous acts against amber in comparison with Part 2 of Art. 240 of the Criminal Code of Ukraine. In this regard, there is a question of interpretation of these types of criminal behavior in order to determine their content and provide appropriate recommendations to practitioners for the correct qualification of actions that constitute a crime under Part 1 of Art. 240-1 of the Criminal Code of Ukraine. It should be noted that in general, these forms of socially dangerous acts for criminal law and science are not new. The issue of the content of illegal extraction was considered, in particular, in the context of the crime of Part 2 of Art. 240 of the Criminal Code of Ukraine on illegal extraction of minerals of national importance in general. The content of the concepts of sale, acquisition, storage, transfer, shipment, transportation was considered in the context of Art. 305-320 of the Criminal Code of Ukraine. The concept of processing was considered in the context of Art. 263-1 of the Criminal Code of Ukraine [12].

It is seen that these concepts can be taken as a basis for determining the content of forms of socially dangerous acts under Art. 240-1 of the Criminal code of Ukraine, but taking into account features of a subject matter of a crime.

Illegal amber mining should be understood as actions that involve its extraction from mineral deposits (pumping, construction of mines, quarries, and so on). First of all, we are talking about prospecting methods of extraction, which, depending on the geological conditions, are carried out by digging (pit excavations) and underground hydraulic washing.

The use of one or another method is determined by a combination of the following factors: 1) the depth of amber-containing deposits; 2) the depth of groundwater and the presence of floodplains; 3) susceptibility of amber-containing deposits to erosion; 4) the content of amber in the ore [13].

The illegality of mining, which is a prerequisite for criminalizing a person's actions, means that mining is carried out without a proper permit. Such permission in accordance with Part 3 of Art. 15 of the Subsoil Code of Ukraine has a special permit for geological study on amber subsoil, including research and development of deposits with subsequent extraction of amber (industrial development of deposits). Amber mining will also be considered illegal in case of deviation from the conditions specified in such a permit (in particular, work on extraction outside the allotted subsoil area or when using unauthorized methods and means). It will be a crime in the case when the permit is forged, obtained as a result of submitting knowingly incorrect information or expired to the authorized body. In particular, according to the current legislation, such a permit is issued for a period of five years.

Illegal sale of amber should be understood as any paid or unpaid forms of their implementation contrary to the law (sale, gift, exchange, payment of debt, loan, pledge, and others). The actions of a person who deliberately sells any other items under the guise of amber for the purpose of seizing money or property should be classified as fraud.

Illegal acquisition of amber should be considered their acquisition in any way: purchase, exchange, acceptance as payment for work performed or services provided, loan, gift, payment of debt, appropriation of found, and so on. Theft of amber (theft or robbery) is not covered by this crime. Such actions should be qualified under Art. Articles 185 and 186 of the Criminal Code of Ukraine.

Illegal storage involves certain intentional actions related to the actual possession of amber in the possession of the guilty person (the person keeps it with them, in a room, storage or other place). It should be borne in mind that criminal liability for such actions occurs regardless of its duration.

Transportation of amber is expressed in its intentional movement by any mode of transport within the territory. It does not matter whether a person is the direct owner of amber to be considered a criminal offense. Transportation is different from moving from one place to another without the use of transportation. Such actions should be considered as storage of amber.

Forwarding of amber consists in sending it by mail, luggage, messenger or in another way from one place to another within the territory of Ukraine. Such crime will be completed from the moment of registration and sending of parcel, luggage, and so on with such items, regardless of whether the addressee received them or not. If such actions have not been fully implemented by those independent of the perpetrator, the actions of the offender should be classified as an attempt to commit a crime.

The transfer of amber should be understood as the direct transfer of amber by hand-to-hand or access to them (for example, by transferring the key from the storage chamber).

Amber processing is the processing of it by giving it other properties or shapes. Such actions, for example, are the processing of amber into marketable products.

An important condition for the criminality of these actions is that the legality of the origin of amber, which is the subject of sale, purchase, storage, transfer, shipment, transportation or processing is not confirmed by relevant documents. This feature reflects the link between the illegal extraction of amber and its subsequent operations: acquisition, storage, transfer, shipment, transportation or processing. Criminal liability arises for performing these operations only with illegally mined amber. This in turn means that the transportation, processing, sale or other actions of amber extracted legally are not criminally punishable.

Another problematic issue in combating illegal amber mining is that illegal transportation or shipment is interpreted in criminal law as carrying within the territory of Ukraine, and therefore is not covered by the concept of "smuggling". The criminal definition of smuggling is enshrined in Art. 201 of the Criminal code of Ukraine as carrying across customs border of Ukraine out of customs control or with concealment from customs control of certain subjects. Such items, in accordance with Art. Art. 201, 201-1, 305 of the Criminal code of Ukraine are: cultural values, poisonous, powerful, explosives, radioactive materials, the weapon or ammunition (except smoothbore hunting weapons or ammunition to it), parts of the firearms, special technical means of secret receipt information, timber or lumber of valuable and rare tree species, narcotic drugs, psychotropic substances, their analogues, precursors and falsified medicines.

Carrying across the customs border of Ukraine outside customs control or with concealment from customs control of other items qualifies under Art. 483 of the Customs code of Ukraine for which administrative responsibility in the form of the penalty of 100 or 200 percent of cost of goods - direct subjects of violation of customs rules with confiscation of these goods, and also the goods, vehicles with specially made storages (hiding places) used for carrying goods - direct objects of violation of customs rules across the customs border of Ukraine or [14].

The current version of Art. 201 of the Criminal Code "Smuggling" appeared in the Criminal Code of Ukraine after the Verkhovna Rada of Ukraine adopted the Law of Ukraine "On Amendments to Certain Legislative Acts of Ukraine on the Humanization of Liability for Offenses in the Sphere of Economic Activity" of November 15, 2011 N 4025-VI [15]. Until now, the subject of smuggling has been formulated as "large-scale goods" and "strategically important raw materials", which included amber and other minerals. But in this edition the subject of smuggling was carried from the disposition of Part 1 of Art. 201 of the Criminal Code with the simultaneous establishment of administrative liability for such actions.

Relevant changes in legislation in practice have led to a significant increase in the manifestations of amber smuggling. 
For example, according to the State Border Guard Service of Ukraine (hereinafter - the State Traffic Police) during 2015, employees of the Volyn customs alone stopped 33 attempts to smuggle precious stones across the customs border. More than $2,955 \mathrm{~kg}$ of amber were seized in cases of violation of customs regulations. The Ministry of Finance of the Republic of Poland provided the following information when asked about the number of arrests of illegal transportation of amber on the Polish-Ukrainian border: "During 2015, 225 cases of illegal transportation of amber were recorded; $19551.0335 \mathrm{~kg}$ of amber were seized. In Bila Podlaska - 101 cases of illegal transportation of amber $(18632.2565 \mathrm{~kg})$. In Bialystok there was one case of transportation of "solar" stone ( $15 \mathrm{~kg}$ of amber). In Olsztyn - 11 cases involved the transportation of amber $(165,597 \mathrm{~kg})$. In Przemyśl - 110 detentions for the transportation of stone (686.28 $\mathrm{kg}$ were seized). In Warsaw - 2 cases (51, $9 \mathrm{~kg}$ of amber). During the first half of 2016, more than $600 \mathrm{~kg}$ of amber was seized in Ukraine on the border with Poland. In $2017,411.7 \mathrm{~kg}$ of amber was seized at the Ukrainian-Polish border. In 2018, during the control at the Polish-Ukrainian border crossing points in Podkarpackie Voivodeship, more than $700 \mathrm{~kg}$ of amber was smuggled. In 2019, almost 700 kilograms of smuggled amber worth more than 600,000 euros were seized by officers of the Criminal Service of the Financial Administration of Slovakia from four citizens of Ukraine who were illegally transporting unprocessed amber [18].

From the above information it can be seen that the application of administrative sanctions does not deter offenders from illegal behavior, which leads to proposals to strengthen the responsibility for such offenses. This is possible by establishing a separate article on criminal liability for amber smuggling.

Criminal law is aware of cases of introduction of special rules on smuggling certain items. For example, Art. 305 of the Criminal code of Ukraine provides responsibility for smuggling narcotic drugs, psychotropic substances, their analogs or precursors or falsified medicines. Similarly, Art. 201-1 provides for a separate corpus delicti of smuggling timber or lumber of valuable and rare species of trees, unprocessed timber, as well as other timber prohibited for export outside the customs territory of Ukraine.

In this regard, it is proposed to supplement the Special Part of the Criminal Code of Art. 240-2 of the following content:

"Amber smuggling:

1. Carrying across the customs border of Ukraine outside customs control or with concealment from customs control of amber, the legality of the origin of which is not confirmed by the relevant documents, - shall be punishable by restriction of liberty for a term of two to three years, or by imprisonment for the same term.

2. The same acts, if committed repeatedly or on a large scale, or by a group of persons, - shall be punishable by imprisonment for a term of four to seven years with confiscation of property.

3. The actions provided for in part one of this article, committed by an official through the use of their official position, - shall be punishable by imprisonment for a term of five to eight years with confiscation of property".

It should be noted that it is unlikely to be appropriate to criminalize such smuggling on a small scale. These offenses have a lower level of public danger, so it would be appropriate to classify them as administrative.

In this regard, we propose to supplement Chapter 68 of the Customs Code of Ukraine with the following article: "Carrying amber across the customs border of Ukraine in small amounts:

1. Carrying across the customs border of Ukraine outside customs control or with concealment from customs control of amber in insignificant amounts, the legality of the origin of which is not confirmed by the relevant documents, - entails a fine of five hundred to one thousand non-taxable minimum incomes.
2. The actions provided for in part one of this article, committed by a person who during the year was prosecuted for committing an offense under this article, - entails the imposition of a fine in the amount of one thousand to two thousand non-taxable minimum incomes".

Note. The small size in this article should be understood as the value of amber which does not exceed the tax-free minimum income of citizens more than ten times.

Other types of illegal amber treatment in Ukraine should be distinguished according to the same principle. We are talking about those provided for in Art. 240-1 of the Criminal Code of Ukraine.

It is proposed to introduce administrative liability in the form of a fine for illegal amber mining, as well as sales, acquisition, storage, transfer, shipment, transportation, processing in small amounts. For other cases, it is proposed to leave criminal liability, but not in the form of a fine, but providing only restriction or imprisonment. These changes will allow, on the one hand, humanizing the responsibility for less socially dangerous forms of illegal amber treatment and, on the other hand, strengthening criminal liability for more dangerous acts.

In this regard, we propose to remove from the sanction of Art. 240-1 of the Criminal code of Ukraine the phrase "... a fine from three thousand to ten thousand non-taxable minimum incomes of citizens..." and to supplement the Code of Ukraine on administrative offenses with the following article: "Illegal extraction, sale, acquisition, transfer, shipment, transportation, processing of amber in small amounts:

1. Illegal extraction of amber, as well as sale, purchase, storage, transfer, shipment, transportation, processing of amber, the legality of which is not confirmed by relevant documents, - entails a fine of five hundred to one thousand nontaxable minimum incomes.

2. The actions provided for in part one of this article, committed by a person who during the year was prosecuted for committing an offense under this article, - entails the imposition of a fine in the amount of one thousand to two thousand non-taxable minimum incomes.

Note. The small size in this article should be understood as the value of amber, which does not exceed the tax-free minimum income of citizens more than ten times".

Conclusions. Summarizing the above, it should be noted that the state protection of the subsoil of Ukraine from illegal amber mining occupies an important place in the system of environmental, economic and social security of Ukraine. Current national legislation offers a number of mechanisms to counter this anti-social phenomenon, but which are imperfect and often inconsistent. The proposed amendments to the current legislation of Ukraine will help improve the legal regulation of amber protection in Ukraine and will create a proper basis for the practical implementation of these rules by law enforcement agencies.

\section{References.}

1. Verkhovna Rada of Ukraine (2003). About the statement of the in struction on application of Classification of reserves and resources of minerals of the state fund of subsoil to amber deposits: the order of the State commission on reserves of minerals from 10.02.2003 No. 29. Retrieved from https://zakon.rada.gov.ua/laws/show/z0155-03\#Text.

2. Verkhovna Rada of Ukraine (2020). On approval of lists of minerals of state and local significance: Resolution of the Cabinet of Ministers of Ukraine of 12.12.1994 No. 827. Retrieved from https://zakon.rada.gov. ua/laws/show/827-94-\%D0\%BF\#Text.

3. Legislation of Ukraine (n.d.). Explanatory note to the draft Law of Ukraine of December 26, 2014 No. 1351-1 "On the extraction and sale of amber". Retrieved from https://ips.ligazakon.net/document/ GH11J1AA?an=4.

4. Rudko, H. I. (2019). Amber deposits of Ukraine and prospects for their development. Mineral resources of Ukraine, (2), 18-21.

5. Tsymbaliuk, V. I. (2019). Problems of legal regulation of amber mining. Young scientist, (12.1), 71-73. 
6. Kazak, R. (2017). Development of Legal Norms on Biodiversity Protection Reflecting EU Trends. Environmental Policy and Law, 47(3-4), 147-152.

7. Verkhovna Rada of Ukraine (2019). On Amendments to Certain Legislative Acts of Ukraine Concerning the Improvement of Legislation on the Extraction of Amber and Other Minerals: Law of Ukraine of December 19, 2019 No. 402. Retrieved from https://zakon.rada.gov.ua/laws/ show/402-20\#Text.

8. Verkhovna Rada of Ukraine (2021). Criminal Code of Ukraine: Law of Ukraine of 05.04.2001 No. 2341-III. Retrieved from https://zakon. rada.gov.ua/laws/show/2341-14\#n2115.

9. Verkhovna Rada of Ukraine (n.d.). Code of Ukraine on subsoil: Law of Ukraine of 27.07.1994 No. 132/94-BP. Retrieved from https://zakon.rada.gov.ua/laws/show/132/94-\%D0\%B2\%D1\%80\#Text.

10. Verkhovna Rada of Ukraine (n.d.). Tax Code of Ukraine: Law of Ukraine of 02.12.2010 No. 2755-VI (2021). Retrieved from https:// zakon.rada.gov.ua/laws/show/2755-17\#Text.

11. Land Code of Ukraine: Law of Ukraine of 25.10.2001 No. 2768III (2021). Retrieved from https://zakon.rada.gov.ua/laws/ show/2768-14\#Text.

12. Melnyk, M. I., \& Khavroniuk, M. I. (Eds.) (2018). Scientific and practical commentary on the Criminal Code of Ukraine $\left(10^{\text {th }} \mathrm{ed}\right.$.). (pp. 825-826; 908-941). Kyiv: VD "Dakor".

13. Volnenko, S.O., Melnychuk, H.V., Kurepa, Ya.S., \& Mamchur, S. V. (2017). Exploratory methods of amber mining in Ukrainian Polissya. News of the Donetsk Mining Institute, 1(40), 118.

14. Verkhovna Rada of Ukraine (n.d.). Customs Code of Ukraine: Law of Ukraine of 13.03.2012 No. 4495-VI. Retrieved from https://zakon. rada.gov.ua/laws/show/1970-12\#Text.

15. Verkhovna Rada of Ukraine (n.d.). On Amendments to Certain Legislative Acts of Ukraine Concerning the Humanization of Liability for Offenses in the Sphere of Economic Activity: Law of Ukraine of 15.10.2011 No. 4025-VI. Retrieved from https://zakon.rada.gov.ua/laws/ show/4025-17.

16. How Ukrainian amber is illegally exported to Poland. Volyn Investigation Agency. Retrieved from https://www.openforest.org.ua/27793/. 17. Amber smuggling was seized on the border with Ukraine. Retrieved from https://forpost.lviv.ua/novyny/22258-na-kordoni-z-ukrainoiuvyluchyly-kontrabandu-burshtynu.

18. In Slovakia, more than 700 kilograms of smuggled amber were seized from Ukraine. Retrieved from https://www.radiosvoboda.org/a/burshtyn-z-ukrajiny-zatrzmaly-na-slovachchyni/30278785.html.

\section{Охорона суспільних відносин у сфері видобутку бурштину в Україні: правовий аспект}

\author{
Ю.А. Холодㅁ, І. М. Погрібний', К. О. Чишко ${ }^{1}$, \\ Д. С. Гета 1 , О. П. Шайтуро ${ }^{2}$
}

1 - Харківський національний університет внутрішніх справ, м. Харків, Україна

2 - Харківський національний університет імені В. Н. Каразіна, м. Харків, Україна, e-mail: opshaituro@karazin.ua

Мета. Визначення правових засобів охорони суспільних відносин у сфері видобутку бурштину в Україні, надання науково-практичного тлумачення охоронних норм законодавства у цій сфері та науково обгрунтованих рекомендацій щодо їх удосконалення.
Методика. Методичну основу дослідження становить система загальних і спеціальних методів пізнання: діалектичний метод застосовувався для пізнання сутності такого явища як охорона суспільних відносин у сфері видобутку бурштину в Україні; системно-структурний при здійсненні аналізу форм суспільно-небезпечних діянь складів злочинів, передбачених ст. ст. 240, 240-1 Кримінального кодексу України; логіко-догматичний під час тлумачення окремих термінів, що вживаються у науках геології, адміністративного та кримінального права, містяться в положеннях чинного законодавства, а також при формулюванні визначень юридичних понять i розробці рекомендацій щодо вдосконалення юридичних норм; порівняльно-правовий - при дослідженні співвідношення суспільно небезпечних діянь, передбачених ст. ст. 201-1, 240, 240-1, 305 Кримінального кодексу України; загальнологічні методи (аналіз, синтез, індукція, дедукція, абстрагування, узагальнення) - при опрацюванні наукових і нормативних джерел.

Результати. У результаті проведеного дослідження встановлена неузгодженість окремих норм кримінального, адміністративного й митного законодавства, що формують склади правопорушень у сфері незаконного видобутку бурштину в Україні та встановлюють види й міру відповідальності за їх вчинення, зокрема: конкуренцію окремих норм, їх неефективність, непропорційність тяжкості покарання за окремі правопорушення ступеню їх суспільної небезпечності. Надано науково-практичне тлумачення форм суспільно-небезпечного діяння, передбаченого ст. 240-1 КК України, проведено порівняльний аналіз кримінальних, адміністративних і митних правопорушень у зазначеній сфері й надані пропозиції з удосконалення кримінального, адміністративного й митного законодавства, нормами якого поставлені під охорону суспільні відносини у сфері видобутку бурштину в Україні.

Наукова новизна. Запропоновано: 1) доповнити Кримінальний кодекс України ст. 240-2, якою передбачити кримінальну відповідальність за контрабанду бурштину; 2) доповнити Главу 68 Митного кодексу України статтею 483-1, якою передбачити адміністративну відповідальність за контрабанду бурштину в невеликих розмірах; 3) доповнити Кодекс України про адміністративні правопорушення статтею 58-2, якою передбачити адміністративну відповідальність за незаконне видобування бурштину, його збут, придбання, зберігання, передачу, пересилання, перевезення, переробку в незначних розмірах.

Практична значимість. Надані пропозиції з удосконалення чинного кримінального, адміністративного й митного законодавства спрямовані на підвищення ефективності протидії правоохоронними органами незаконному видобутку бурштину в Україні.

Ключові слова: охорона надр України, незаконний видобуток бурштину, кримінальна та адміністративна відповідальність

The manuscript was submitted 29.03.21. 